Çukurova Üniversitesi Mühendislik Mimarlık Fakültesi Dergisi, 29(2), 131-140 ss., Aralık 2014

Çukurova University Journal of the Faculty of Engineering and Architecture, 29(2), pp. 131-140, December 2014

\title{
Ege Bölgesindeki Termik Santrallerden Alınan Uçucu Küllerin Liç Karakteristiklerinin Belirlenmesi
}

\author{
Mehmet TÜRKMENOĞLU ${ }^{* 1}$, Mesut ANIL ${ }^{2}$, Fatih Şevki ERKUŞ ${ }^{3}$

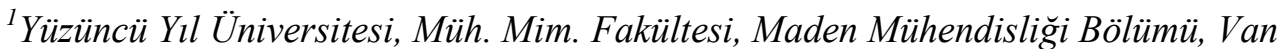 \\ ${ }^{2}$ Cukurova Üniversitesi, Müh. Mim Fakültesi, Maden Mühendisliği Bölümü, Adana

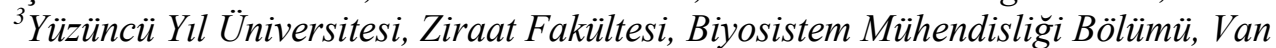

Geliş tarihi: 27.10.2014 Kabul tarihi:13.11.2014

\section{Özet}

Türkiye'deki termik santrallerde, yanma sonucu oluşan atıkların ancak \%65 kadarı kül barajlarında depolanmaktadır. Geriye kalan atıklar, insan sağlığı ve çevre (toprak, hava ve su) için potansiyel tehlike oluşturmaktadır. Bu atıkların liç karakteristiklerinin belirlenmesi, bu atıkların depolandıkları alandaki davranışlarının anlaşılması açısından önemlidir. Bu çalışmada, Ege Bölgesi'nde yer alan dört adet termik santralde düşük kalorili linyit kömürünün yakılması sonucu ortaya çıkan uçucu küllerin mineralojik, morfolojik ve kimyasal analizleri yapılarak liç karakteristikleri belirlenmiştir. Uçucu küllerdeki ağır metal $(\mathrm{Pb}, \mathrm{Cd}, \mathrm{Cr}, \mathrm{Cu}, \mathrm{Ni}, \mathrm{Zn}, \mathrm{Co}$ ve $\mathrm{Mn})$ miktarları ve bu metallerin küllerden suya geçiş değerleri tespit edilmiştir. Uçucu küllerin tamamında Cd metali, yer kabuğu üst bölgesi ortalama değerinin $(0,2 \mathrm{mg} / \mathrm{kg})$ en az 10 katı oranında zenginleşmiştir. Çalışmada en düşük liç veriminin çinkoda $(\% 0,2-0,6)$ olduğu, en yüksek liç veriminin ise kadmiyum metalinde $(\% 3,08-16,50)$ olduğu tespit edilmiştir.

Anahtar Kelimeler: Ege Bölgesi, Termik santral, Uçucu kül, Liç, Ağır metal

\section{Determination of Leaching Characteristics of Fly Ashes Obtained from Thermal Power Plants in Aegean Region}

\begin{abstract}
Only up to $65 \%$ of the wastes generated by thermal power plants are being disposed of in ash dams in Turkey. Remaining wastes may pose a potential hazard to the human health or the environment (soil, air, water). Determination of the leaching characteristics of thermal power plant wastes is a fundamental property that defines environmental importance of the elements in these wastes. In this study, determination of leaching characteristics of fly ashes generated at four thermal power plants burning lowcalorie lignite in the Aegean region was examined by mineralogical, morphological and chemical analyzes. The total heavy metals $(\mathrm{Pb}, \mathrm{Cd}, \mathrm{Cr}, \mathrm{Cu}, \mathrm{Ni}, \mathrm{Zn}, \mathrm{Co}$ and $\mathrm{Mn})$ in fly ash and their leaching amounts were determined. $\mathrm{Cd}$ metal in all of the fly ashes was at least enriched over the average earth's crust values by 10 -fold. It was found that the maximum leach yield achieved by cadmium $(3.08-16,50 \%)$, whereas the leach yield of zinc $(0,2-0,6 \%)$ was the minimum.
\end{abstract}

Keywords: Aegean region, Thermal power plant, Fly Ash, Leach, Heavy metal

\footnotetext{
" Yazışmaların yapılacağı yazar: Mehmet TÜRKMENOĞLU, YYÜ Müh. Mim. Fak. Maden Müh. Bölümü,Van.mehmetturkmenoglu77@gmail.com
} 


\section{GİRIŞ̧}

MTA’nın 2013 yılı linyit kömürü raporuna göre Türkiye'nin toplam linyit rezervi; 13,8 milyar ton'dur [1]. 2012 y1lında üretilen 68,1 milyon ton linyitin \%81,7'si elektrik üretim amacıyla termik santrallerde kullanılmıştır [2]. Çünkü, ülkemizdeki linyitlerin kül ve kükürt oranları yüksek, 1sıl değerleri ise ısınma amaçlı kullanılmayacak kadar düşüktür [3]. Yerli linyitle çalışan termik santraller ülkemizde en çok Ege bölgesinde yer almaktadır. Yerli kömürle çalışan ve 50 MW'tan büyük 20 adet termik santralin 6 tanesi Ege Bölgesi'ndedir.

Termik Santrallerde linyit kömürünün yakılması sonucunda büyük miktarlarda katı yanma ürünleri oluşmaktadır. $\mathrm{Bu}$ ürünlerin $\% 80$ gibi büyük bir çoğunluğunu, baca tarafından çekilen gazlarla beraber yukarı sürüklenen ve uçucu kül adı verilen çok ince boyutlu $(1-150 \mu \mathrm{m})$ kül tanecikleri oluşturmaktadır [4]. Uçucu küllerin içindeki tanelerin 11 temel morfolojik yapıda (şekilsiz saydam taneler, opak küresel taneler, vb.) oldukları belirlenmiştir [5]. Uçucu küllerin kimyasal bileşenleri, kullanılan kömürün cinsine ve kömürde bulunan minerallere bağlıdır. Bir çok uçucu külün \%85'inden fazlası $\mathrm{SiO}_{2}, \mathrm{CaO}, \mathrm{Fe}_{2} \mathrm{O}_{3}$, $\mathrm{MgO}, \mathrm{Al}_{2} \mathrm{O}_{3}$ ve $\mathrm{SO}_{3}$ 'ten oluşmaktadır [6]. Ayrıca, uçucu küllerin bünyesinde; $\mathrm{Sb}, \mathrm{As}, \mathrm{Be}, \mathrm{Cd}, \mathrm{Cr}, \mathrm{Cu}$, $\mathrm{Pb}, \mathrm{Hg}, \mathrm{Ni}, \mathrm{Se}, \mathrm{Ag}, \mathrm{Zn}, \mathrm{vb}$. elementler bulunmakta, kömürün yanması esnasında radon, uranyum ve toryum gibi radyoaktif elementler açığa çıkmaktadır [7].

Bu çalışmada, Ege bölgesinde yer alan dört adet termik santralde düşük kalorili linyit kömürünün yakılması sonucu ortaya çıkan uçucu küllerin liç karakteristikleri belirlenmiştir. Uçucu küllerdeki ağır metal ( $\mathrm{Pb}, \mathrm{Cd}, \mathrm{Cr}, \mathrm{Cu}, \mathrm{Ni}, \mathrm{Zn}, \mathrm{Co}$ ve $\mathrm{Mn}$ ) miktarları ve bu metallerin küllerden suya geçiş oranları belirlenmiştir. Böylece, farklı karakterdeki uçucu küllerin depolandıkları alanın yakın çevresinde toprak ve yeraltı suyuna ağır metaller açısından bir kirlilik etkisinin olup olmayacağı liç işlemi ile belirlenmeye çalışılmıştır.

\section{MATERYAL VE METOD}

Ege Bölgesi'nde yer alan ve yerli linyitle elektrik üretimi yapan termik santraller; Seyitömer (1-4 Ünite), Soma A ve B, Tunçbilek A ve B, Yatağan, Kemerköy ve Yeniköy termik santralleridir. Bu çalışmada, Seyitömer, Soma, Tunçbilek termik santrallerinden uçucu kül örneği alınmıştır. Yatağan, Kemerköy ve Yeniköy termik santrallerinde Güney Ege Linyit işletmelerince çıkartılan linyit kömürü yakıldığı için, sadece Yatağan termik santralinden uçucu kül alınmıştır.

Alınan kül örnekleri Çukurova Üniversitesi Maden Mühendisliği Bölümü Kimya Laboratuvarı'ndan kimyasal analizlere [8] ve liç işlemlerine [9] tabi tutulmuştur. Kül örnekleri üzerine 1/1'lik $10 \mathrm{ml} \mathrm{HNO}_{3}$ ilave edilip kaynama noktasının hemen altına kadar isıtılmıştır. Çözünme tamamlandıktan sonra çözelti hacmi $5 \mathrm{ml}$ oluncaya kadar kaynatılmadan buharlaştırılmıştır. Çözelti soğutulduktan sonra $2 \mathrm{ml}$ deiyonize su ve $3 \mathrm{ml}$ \%30'luk hidrojen peroksit, köpürme bitinceye kadar ilave edilmiştir. Çözelti, çözünmemiş katının alınması için mavi bant süzgeç kağıdından süzülmüştür. $\mathrm{Bu}$ işlemlerle, kül örneklerinin içerdikleri tüm ağır metaller çözeltiye alınmıştır.

Kül örneklerinin liç karakteristiklerinin belirlenmesi için ise, atıkların özütlenmesi için kullanılan TS EN 12457-3'te belirtilen işlemler uygulanmıştır. 10 litre/kg oranını sağlayacak şekilde kül tartılmış ve üzerine $100 \mathrm{ml}$ deiyonize su eklenmiştir. Karıştırıcının devri 10 d/dk’ya ayarlanarak 24 saat boyunca karıştırılmıştır. Süre sonunda katı faz mavi bant süzgeç kâğıdından süzülmüştür.

Uçucu küllere uygulanan liç işlemi Çizelge 1'de verilmiştir. Liç işlemleri seri olarak gerçekleştirilmiştir. Birinci günün sonunda süzgeç kâğıdında biriken kalıntı tekrar kapaklı plastik kap içerisine alınmış ve diğer işlemler tekrarlanarak seri liç işlemi 5 kez tekrarlanmıştır.

Küllerin analizi sırasında elde edilen çözeltilerin ve 5 günlük seri liç işlemleri sonrası elde edilen liç çözeltilerinin ağır metal içerikleri $(\mathrm{Pb}, \mathrm{Cd}, \mathrm{Cr}, \mathrm{Cu}$, $\mathrm{Ni}$, Zn, Co ve Mn), Atomik Absorbsiyon Spektrometresi'nde analiz edilmiştir [10]. Kullanılan standartların adları ve numaraları Çizelge 2'de verilmiştir. Uçucu külün ve taban 
külünün mineralojik yapılarının belirlenmesi için XRD analizleri ve morfolojik özelliklerinin belirlenmesi için de SEM analizleri yapılmıştır. Her iki analiz de TÜBİTAK MAM'da gerçekleştirilmiştir.

\section{ARAŞTIRMA BULGULARI}

\subsection{Mineralojik Analizler}

Uçucu küllerdeki temel (major) mineraller kuvars, anhidrit, illit, mullit ve feldispatlar (albit, anortit) gibi alüminyum silikat mineralleridir.
Uçucu küller, demir oksitleri (hematit, manyetit) ve kalsiyum oksitleri de içermektedir. Ayrıca, uçucu küllerde amorf madde tespit edilmiş, ancak minerallerin yüzdeleri belirlenirken hesaba katılmamıştır.

XRD analizleri sonucunda uçucu küllerde belirlenen minerallerin kimyasal formülleri ve $\%$ oranları Çizelge 3-6'da verilmiştir. Seyitömer termik santrali uçucu külünde başlıca illit, kuvars ve hematit mineralleri, Tunçbilek termik santrali uçucu külünde ise, kuvars, mullit, hematit ve manyetit minerallerinin olduğu tespit edilmiştir.

Çizelge 1. Termik Santrallerden alınan uçucu kül örneklerine uygulanan liç işlemi

\begin{tabular}{|c|c|c|c|c|}
\hline Liç İşlemi & $\begin{array}{c}\text { Kül/Çözücü } \\
\text { Oranı }\end{array}$ & Süre & $\begin{array}{c}\text { Karıştırma } \\
\text { hızı }\end{array}$ & $\begin{array}{c}\text { Kullanılan } \\
\text { Reaktif }\end{array}$ \\
\hline Seri Liç (5 gün) & $10 \mathrm{~g} /$ litre & 24 saat & 10 devir/dk & Deiyonize Su \\
\hline
\end{tabular}

Çizelge 2. Analizler yapılırken kullanılan standartlar ve adları

\begin{tabular}{|c|c|c|c|}
\hline No & Örnek & Standart & Yöntem \\
\hline $\mathbf{1}$ & Kül Analizleri & $\begin{array}{c}\text { TS 12088 } \\
\text { Ekim 1996 }\end{array}$ & $\begin{array}{c}\text { Katı atılar-Ağır metal tayini-Atomik } \\
\text { Absorbsiyon Spektrofotometrik Metot }\end{array}$ \\
\hline $\mathbf{2}$ & $\begin{array}{c}\text { Uçucu Küllerin } \\
\text { Liçi }\end{array}$ & $\begin{array}{c}\text { TS EN 12457-3 } \\
\text { Ocak 2004 }\end{array}$ & $\begin{array}{c}\text { Atıkların nitelendirilmesi-Katıdan özütleme } \\
\text { analizi-granül katı atıkların ve çamurların } \\
\text { katı özütlemesi deneyi: Bölüm3 }\end{array}$ \\
\hline $\mathbf{3}$ & $\begin{array}{c}\text { Liç Çözeltilerinin } \\
\text { Analizleri }\end{array}$ & $\begin{array}{c}\text { TS EN ISO 15586 } \\
\text { Ocak 2004 }\end{array}$ & $\begin{array}{c}\text { Su kalitesi-Grafit firınlı Atomik } \\
\text { Absorbsiyon Spektrometresi kullanılarak } \\
\text { eser elementlerin tayini }\end{array}$ \\
\hline
\end{tabular}

Çizelge 3. Seyitömer Termik Santrali’nden alınan uçucu kül içerisinde XRD ölçümü sonucunda belirlenen minerallerin yüzde dağılımı*

\begin{tabular}{|c|c|c|c|}
\hline $\mathbf{N o}$ & Belirlenen mineraller & Kimyasal Formül & \% Miktari \\
\hline $\mathbf{1}$ & İllit & $\left(\mathrm{K}, \mathrm{H}_{3} \mathrm{O}\right) \mathrm{Al}_{2} \mathrm{Si}_{3} \mathrm{AlO}_{10}(\mathrm{OH})_{2}$ & 38,7 \\
\hline $\mathbf{2}$ & Kuvars & $\mathrm{SiO}_{2}$ & 22,5 \\
\hline $\mathbf{3}$ & Hematit & $\mathrm{Fe}_{2} \mathrm{O}_{3}$ & 19,8 \\
\hline $\mathbf{4}$ & Feldispat (Anortit) & $\mathrm{CaAl}_{2} \mathrm{Si}_{2} \mathrm{O}_{8}$ & 12,9 \\
\hline $\mathbf{5}$ & Anhidrit & $\mathrm{CaSO}_{4}$ & 6,1 \\
\hline
\end{tabular}

* Kristal formdaki mineral madde miktarı dağılımıdır, amorf madde hesaba katılmamıştır. 
Çizelge 4. Tunçbilek Termik Santrali'nden alınan uçucu kül içerisinde XRD ölçümü sonucunda belirlenen minerallerin yüzde dağılımı*

\begin{tabular}{|c|c|c|c|}
\hline No & Belirlenen mineraller & Kimyasal Formül & \% Miktari \\
\hline $\mathbf{1}$ & Kuvars & $\mathrm{SiO}_{2}$ & 43,5 \\
\hline $\mathbf{2}$ & Mullit & $\mathrm{Al}_{6} \mathrm{Si}_{2} \mathrm{O}_{13}$ & 29,4 \\
\hline $\mathbf{3}$ & Hematit & $\mathrm{Fe}_{2} \mathrm{O}_{3}$ & 14,5 \\
\hline $\mathbf{4}$ & Manyetit & $\mathrm{Fe}_{3} \mathrm{O}_{4}$ & 9,3 \\
\hline $\mathbf{5}$ & Anhidrit & $\mathrm{CaSO}_{4}$ & 3,3 \\
\hline
\end{tabular}

* Kristal formdaki mineral madde miktarı dağılımıdır, amorf madde hesaba katılmamıştır.

Çizelge 5. Yatağan Termik Santrali’nden alınan uçucu kül içerisinde XRD ölçümü sonucunda belirlenen minerallerin yüzde dağılımı*

\begin{tabular}{|c|c|c|c|}
\hline No & Belirlenen mineraller & Kimyasal Formül & \% Miktarı \\
\hline $\mathbf{1}$ & Kuvars & $\mathrm{SiO}_{2}$ & 37,6 \\
\hline $\mathbf{2}$ & Illit & $\left(\mathrm{K}, \mathrm{H}_{3} \mathrm{O}\right) \mathrm{Al}_{2} \mathrm{Si}_{3} \mathrm{AlO}_{10}(\mathrm{OH})_{2}$ & 15,6 \\
\hline $\mathbf{3}$ & Feldispat (Anortit) & $\mathrm{CaAl}_{2} \mathrm{Si}_{2} \mathrm{O}_{8}$ & 16,3 \\
\hline $\mathbf{4}$ & Feldispat (Albit) & $\mathrm{NaAlSi}_{3} \mathrm{O}_{8}$ & 12,6 \\
\hline $\mathbf{5}$ & Anhidrit & $\mathrm{CaSO}$ & 12,6 \\
\hline $\mathbf{6}$ & Portlandit & $\mathrm{Ca}(\mathrm{OH})_{2}$ & 2,7 \\
\hline $\mathbf{7}$ & Kireç & $\mathrm{CaO}$ & 2,6 \\
\hline
\end{tabular}

* Kristal formdaki mineral madde miktarı dağılımıdır, amorf madde hesaba katılmamıştır.

Çizelge 6. Soma Termik Santrali'nden alınan uçucu kül içerisinde XRD ölçümü sonucunda belirlenen minerallerin yüzde dağılımı*

\begin{tabular}{|c|c|c|c|}
\hline No & Belirlenen mineraller & Kimyasal Formül & \% Miktarı \\
\hline $\mathbf{1}$ & Kuvars & $\mathrm{SiO}_{2}$ & 25,3 \\
\hline $\mathbf{2}$ & Mullit & $\mathrm{Al}_{6} \mathrm{Si}_{2} \mathrm{O}_{13}$ & 20,5 \\
\hline $\mathbf{3}$ & Feldispat (Anortit) & $\mathrm{CaAl}_{2} \mathrm{Si}_{2} \mathrm{O}_{8}$ & 19,8 \\
\hline $\mathbf{4}$ & Feldispat (Albit) & $\mathrm{NaAlSi}_{3} \mathrm{O}_{8}$ & 11,2 \\
\hline $\mathbf{5}$ & Anhidrit & $\mathrm{CaSO}_{4}$ & 13,6 \\
\hline $\mathbf{6}$ & Kireç & $\mathrm{CaO}$ & 5,0 \\
\hline $\mathbf{7}$ & Kalsit & $\mathrm{CaCO}$ & 2,8 \\
\hline $\mathbf{8}$ & Portlandit & $\mathrm{Ca}(\mathrm{OH})_{2}$ & 1,8 \\
\hline
\end{tabular}

* Kristal formdaki mineral madde miktarı dağılımıdır, amorf madde hesaba katılmamıștır. 
Yatağan termik santrali uçucu külünde en fazla kuvars, illit, feldispatlar (albit ve anortit) ve anhidrit mineralleri bulunurken, Soma termik santrali uçucu külünde ise, kuvars, mullit, feldispatlar (albit ve anortit) ve anhidrit mineralleri belirlenmiştir.

\subsection{Morfolojik Analizler}

Küllerin partikül boyutu özellikleri, elementlerin liç karakteristikleri hakkında bilgi vermektedir. Gözenekli olmayan kesintisiz dış yüzeye ve yoğun iç yüzeye sahip parçacıklar, ağır metallerin liç edilmesini önleyebilir veya sıkıca alüminyum silikat ağına tutulmasını sağlayabilir $[11,12,13]$. Şekil 1'den Şekil 8'e kadar kül örneklerinin çeşitli kristal yapılarını gösteren SEM fotoğrafları verilmiştir. Uçucu küller, baca gazı akımında maruz kaldıkları yüksek sıcaklıklar nedeniyle düzenli, küresel ve pürüzsüz yüzeylere sahip olabilmektedirler. Ayrıca, düzensiz amorf yapılara sıkça rastlanmaktadır.

Fisher ve Natusch aydınlatmalı ve elektron mikroskoplarla yaptıkları morfolojik çalışmalarla, uçucu küllerin heterojen bir yapıya ve çok farklı tane şekillerine sahip olduklarını belirlemişlerdir [5]. Termik santrallerden alınan uçucu kül örneklerinin 1.000 kattan 30.000 kata kadar değişen oranlarda büyütülerek çekilen SEM görüntülerinde, belirlenen 11 temel morfolojik yapıdan hangilerinin gözlendiği aşağıda listelenmiştir.

Seyitömer termik santrali uçucu küllerinin SEM görüntülerinde; şekilsiz saydam taneler, şekilsiz opak taneler, şekilsiz opak ve saydam karışık taneler, opak küresel taneler ile yüzeylerinde veya içinde kristal oluşumlu küresel taneler görülmektedir.

Tunçbilek termik santrali uçucu küllerinin SEM görüntülerinde; şekilsiz saydam taneler, şekilsiz opak taneler, köşeli delikli opak taneler, saydam katı küresel taneler ile yüzeylerinde veya içinde kristal oluşumlu küresel taneler görülmektedir.

Yatağan termik santrali uçucu küllerinin SEM görüntülerinde; şekilsiz opak ve saydam karışık taneler, plerospheres (içi küresel taneciklerle dolu küresel taneler ile yüzeylerinde veya içinde kristal oluşumlu küresel taneler görülmektedir.

Soma termik santrali uçucu küllerinin SEM görüntülerinde; şekilsiz opak ve saydam karışık taneler, yuvarlak kabarcıklı opak ve saydam karışık taneler ve cenospheres (içi gaz dolu küresel taneciklerle dolu küresel taneler) görülmektedir.

\subsection{Kimyasal Analizler}

Uçucu kül örneklerinde belirlenen ağır metal konsantrasyonları (mg/kg) Çizelge 7'de, elementlerin yer kabuğu üst bölgesindeki ortalama değerleri [14] ve kömürlerdeki ortalama miktarları [15] ile birlikte verilmiştir.

Herhangi bir elementin yerkabuğundaki ortalama değerin 6 katına ulaşması, o metalin zenginleştiğinin göstergesidir. [15]. Uçucu küllerin ağır metal analiz sonuçları küllerdeki $\mathrm{Co}, \mathrm{Cu}, \mathrm{Cr}$, $\mathrm{Pb}$ ve $\mathrm{Zn}$ metallerinin yerkabuğu üst bölgesinden daha fazla olduğu, Mn miktarlarının ise daha az olduğu belirlenmiştir.

Seyitömer ve Tunçbilek termik santrallerinin uçucu külleri, kadmiyum ve nikelce yerkabuğu üst bölgesine göre zenginleşmiştir. Soma termik santrali uçucu külü kadmiyum açısından, Yatağan termik santrali uçucu külü de kadmiyum ve çinko açısından yerkabuğuna göre zenginleşmiştir. Ayrıca, tüm uçucu küllerin kömürlere göre tüm metaller açısından zenginleştiği belirlenmiştir.

Kömür yakıldığı zaman, içerdiği minerallerin çoğunluğu küle dönüşürken, bu minerallerin bir kısmı parçalanmakta, bir kısmı da olduğu gibi küle geçmektedir. Kömürde 60'tan fazla element bulunabilmektedir. $\mathrm{Bu}$ elementlerin genellikle tonda gram olarak ifade edilen konsantrasyonları bir sahadan ötekine, hatta bir damar içinde alttan üste değişebilmektedir [16].

\subsection{Liç Analizleri}

Elementlerin liç çözeltilerindeki konsantrasyonları, hem numunedeki toplam konsantrasyonunun ve hem de liç çözeltisindeki konsantrasyonunun bir 


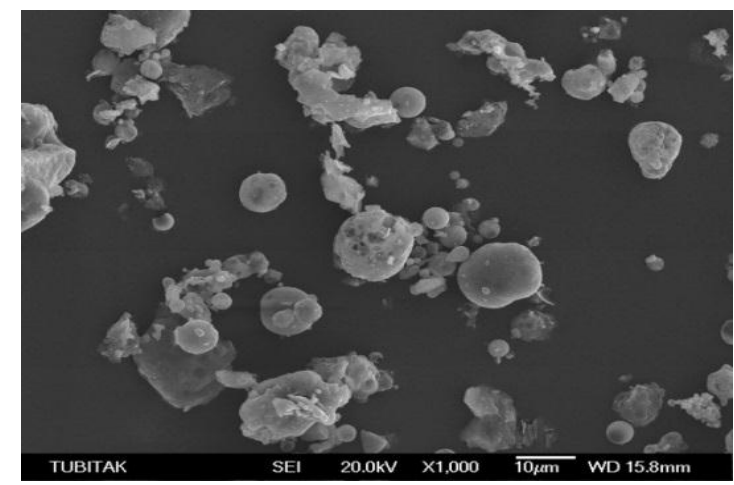

Şekil 1. Seyitömer T.S. uçucu külü SEM görüntüsü (1000 kat büyütülmüş)

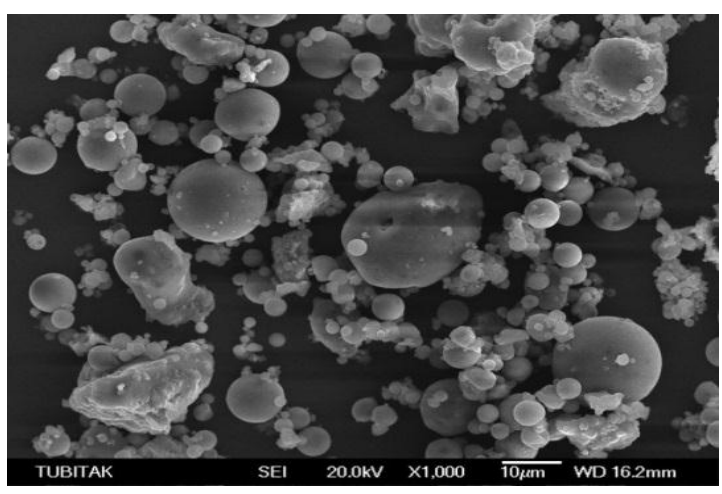

Şekil 3. Tunçbilek T.S. uçucu külü SEM görüntüsü (1.000 kat büyütülmüş)

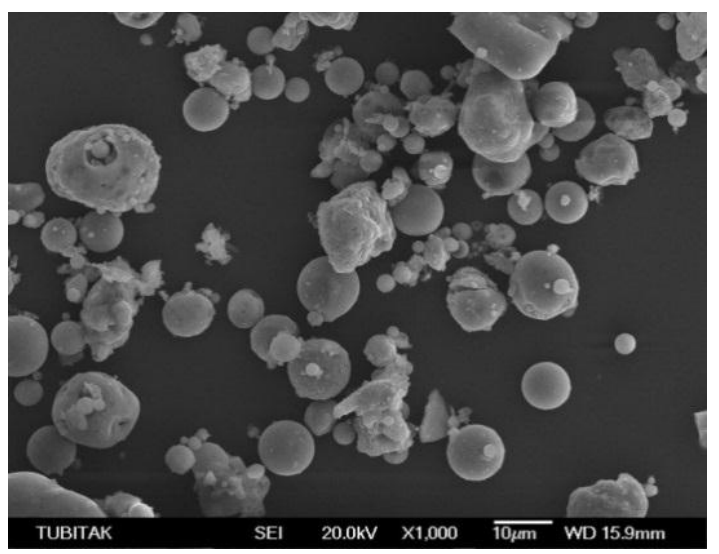

Şekil 5. Yatağan T.S. uçucu külü SEM görüntüsü (1.000 kat büyütülmüş)

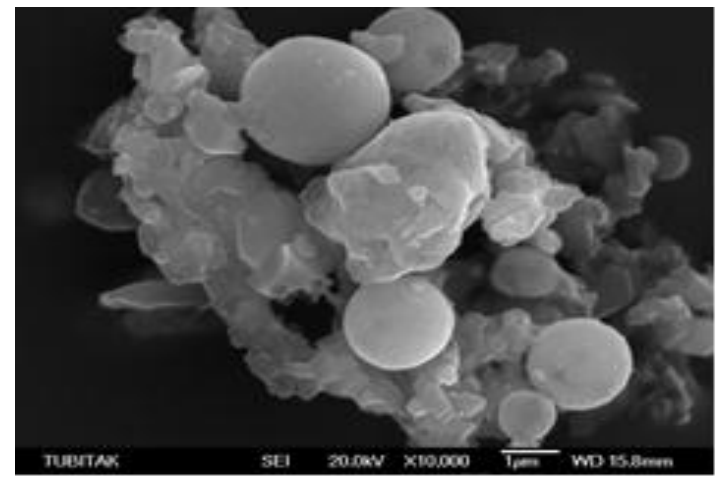

Şekil 2. Seyitömer T.S. uçucu külü SEM görüntüsü (10.000 kat büyütülmüş)

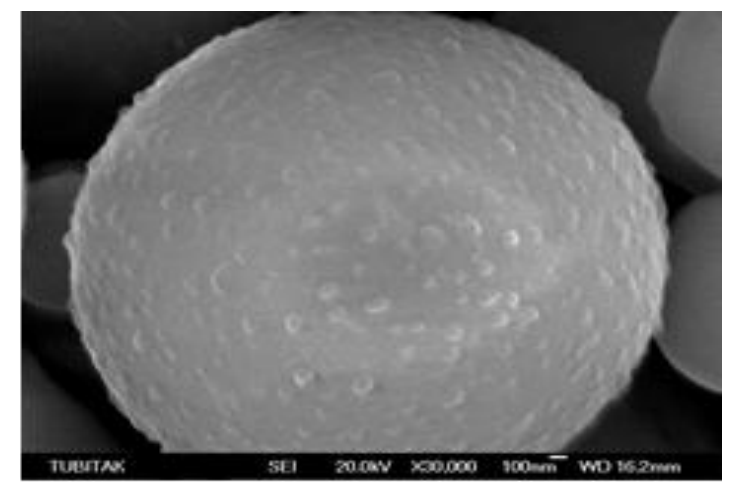

Şekil 4. Tunçbilek T.S. uçucu külü SEM görüntüsü (30.000 kat büyütülmüş)

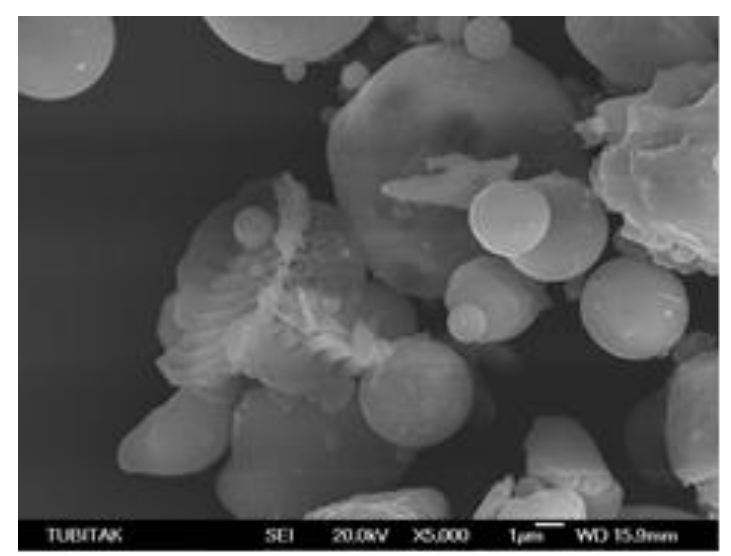

Şekil 6. Yatağan T.S. uçucu külü SEM görüntüsü (5.000 kat büyütülmüş)

Ç.Ü.Müh.Mim.Fak.Dergisi, 29(2), Aralık 2014 


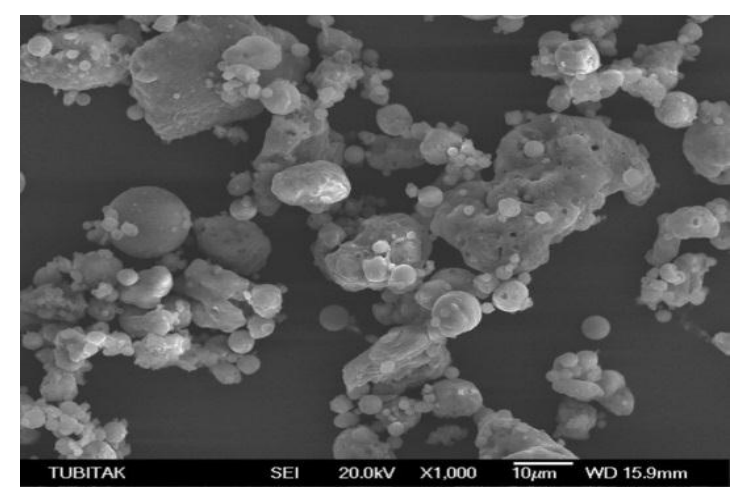

Şekil 7. Soma T.S. uçucu külü SEM görüntüsü (1.000 kat büyütülmüş)

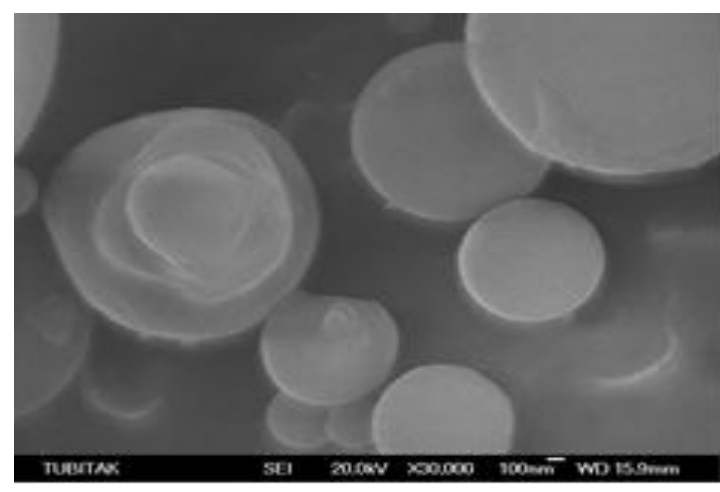

Şekil 8. Soma T.S. uçucu külü SEM görüntüsü (5.000 kat büyütülmüş)

Çizelge 7. Ağır metallerin (mg/kg), Uçucu küllerde, yer kabuğu üst bölgesinde ve kömürlerde belirlenen miktarları

\begin{tabular}{|c|c|c|c|c|c|c|}
\hline $\begin{array}{c}\text { Ağır } \\
\text { Metal }\end{array}$ & $\begin{array}{c}\text { Seyitömer } \\
\text { T.S. }\end{array}$ & $\begin{array}{c}\text { Tunçbilek } \\
\text { T.S. }\end{array}$ & $\begin{array}{c}\text { Yatağan } \\
\text { T.S. }\end{array}$ & $\begin{array}{c}\text { Soma } \\
\text { T.S. }\end{array}$ & $\begin{array}{c}\text { Yerkabuğu } \\
\text { (Ortalama) }\end{array}$ & $\begin{array}{c}\text { Kömür } \\
\text { (Ortalama) }\end{array}$ \\
\hline $\mathbf{P b}$ & 49,8 & 16,4 & 48,2 & 49,9 & 13 & 6,6 \\
\hline $\mathbf{C d}$ & 2,01 & 1,95 & 3,86 & 2,00 & 0,2 & 0,2 \\
\hline $\mathbf{C r}$ & 417,5 & 296,7 & 82,0 & 64,9 & 100 & 15 \\
\hline $\mathbf{C u}$ & 99,4 & 34,8 & 64,8 & 45,4 & 55 & 15 \\
\hline $\mathbf{N i}$ & 1292,3 & 515,0 & 98,6 & 69,5 & 75 & 9,0 \\
\hline $\mathbf{Z n}$ & 524,9 & 262,2 & 488,8 & 405,1 & 70 & 18 \\
\hline $\mathbf{C o}$ & 89,5 & 46,8 & 49,3 & 39,7 & 25 & 4,2 \\
\hline $\mathbf{M n}$ & 546,7 & 690,6 & 320,3 & 186,2 & 950 & 153 \\
\hline
\end{tabular}


fonksiyonudur [17]. Liç karakteristiği bir elementin çevresel önemini tanımlayan temel bir özelliktir [18]. Bu çalışmada 8 farklı ağır metal açısından toplam içerikleri belirlenen, dört adet termik santralin uçucu küllerinden suya geçen ağır metal miktarları Türk standardında verilen seri liç yöntemine göre belirlenmiştir (Çizelge 8). Elde edilen liç çözeltilerin ağır metal içerikleri belirlenmiş ve bu miktarlar küllerde bulunan toplam ağır metal miktarlarına oranlanarak, uçucu küllerden suya ağır metal liç verimi (\% olarak) hesaplanmıştır (Çizelge 9). Termik santrallerden alınan küllerin 5 günlük liç işlemleri sonucunda suya geçen ağır metal miktarları incelendiğinde; Seyitömer termik santrali uçucu külünden suya en çok krom ve nikelin geçtiği, Tunçbilek Termik Santrali'nden suya en çok krom ve kobaltın geçtiği, Yatağan termik santrali uçucu küllerinden ve Soma termik santrali uçucu küllerinden suya; bakır, çinko ve mangan hariç diğer metallerin yoğun bir şekilde geçtiği belirlenmiştir.

Uçucu küllere uygulanan saf su ile 5 günlük seri liç işlemi sırasında, tüm ağır metallerin liç işleminin 5. günün sonunda tamamlandığı belirlenmiştir. 5 gün boyunca suya geçen metallerin toplam miktarı, küllerin içerisinde bulunan ağır metallere oranlanarak liç verimi hesaplanmıştır. Kül örneklerinden liç çözeltilerine ağır metal geçiş verimleri incelendiğinde; en düşük geçişin çinkoda olduğu, en yüksek oranların ise kadmiyum metalinde olduğu gözlenmiştir.

Seyitömer termik santrali liç verimlerinde en yüksek değer \%4,48 ile kadmiyumda, Tunçbilek termik santrali liç verimlerinde en yüksek değer yine \%3,08 ile kadmiyumda görülmüştür. Yatağan termik santrali liç verimlerinde en yüksek değerler $\% 8,03$ ile kadmiyumda ve \%4,17 ile kurşunda belirlenirken, Soma termik santrali liç verimlerinde en yüksek değerler, \%16,50 ile kadmiyumda ve $\% 9,49$ ile kromda belirlenmiştir.

\section{SONUÇLAR}

Dört farklı termik santralden alınan uçucu kül örnekleri üzerinde gerçekleştirilen deneyler neticesinde elde edilen sonuçlar aşağıda özetlenmiştir;

* Uçucu küllerin ağır metal analiz sonuçları küllerdeki $\mathrm{Co}, \mathrm{Cu}, \mathrm{Cr}, \mathrm{Pb}$ ve $\mathrm{Zn}$ metallerinin yerkabuğu üst bölgesinden daha fazla olduğunu, Mn miktarlarının ise daha az olduğunu göstermiştir. Uçucu küllerin tamamı Cd metalince (tüm küllerde yer kabuğu üst bölgesi ortalama değerinin en az 10 katı) zenginleşirken, Seyitömer $(1292,3 \mathrm{mg} / \mathrm{kg})$ ve Tunçbilek $(515 \mathrm{mg} / \mathrm{kg})$ termik santralleri uçucu külleri nikelce zenginleşmiştir.

* Liç çözeltilerinin ağır metal içerikleri incelendiğinde; Seyitömer termik santrali uçucu külünden suya en çok krom $(3,06 \mathrm{mg} / \mathrm{l})$ ve nikelin $(1,38 \mathrm{mg} / \mathrm{l})$ geçtiği, Tunçbilek termik santralinden suya en çok kromun $(3,51 \mathrm{mg} / \mathrm{l})$ geçtiği, Yatağan termik santrali uçucu küllerinden ve Soma termik santrali uçucu küllerinden suya; bakır, çinko ve mangan hariç diğer metallerin yoğun bir şekilde geçtiği belirlenmiştir.

* Yatağan termik santrali uçucu külünden suya; 8,03 mg/l Cd, 4,17 mg/l Pb, 3,73 mg/l Co, 3,72 $\mathrm{mg} / \mathrm{l} \mathrm{Cr}$ ve 3,05 mg/l Ni liç olmuştur. Soma termik santrali uçucu külünden suya; $16,50 \mathrm{mg} / \mathrm{l} \mathrm{Cd}, 9,49$ $\mathrm{mg} / \mathrm{l} \mathrm{Cr}, 6,45 \mathrm{mg} / \mathrm{l} \mathrm{Ni}, 6,35 \mathrm{mg} / \mathrm{l} \mathrm{Pb}$ ve $5,67 \mathrm{mg} / \mathrm{l}$ $\mathrm{Co}$ liç olmuştur. $\mathrm{Bu}$ değerler, izlenen bu ağır metallerin yer altı sularını kirletme riski olduğunu ve küllerin depolandığı yakın çevredeki topraklarda birikme ihtimali olduğunu göstermektedir.

* Seri liç işlemlerinde tüm ağır metallerin suya geçişi beşinci günün sonunda tamamlanmıştır. Kül örneklerinden liç çözeltilerine ağır metal geçiş verimlerinde en düşük geçişin çinkoda olduğu, en yüksek oranların ise kadmiyum metalinde olduğu gözlenmiştir.

* Küllerin liç verimlerinde en yüksek değerler; Seyitömer termik santrali külü $\% 4,48$ ile kadmiyumda, Tunçbilek termik santrali külünde \%3,08 ile kadmiyumda, Yatağan termik santrali külünde \%8,03 ile kadmiyumda Soma termik santrali külünde \%16,50 ile kadmiyumda ve \%9,49 ile kromda belirlenmiştir. 
Çizelge 8. Uçucu küllerin 5 günlük liç çözeltilerinin toplam ağır metal içerikleri

\begin{tabular}{|c|c|c|c|c|c|c|c|c|}
\hline $\begin{array}{c}\text { Termik } \\
\text { Santral }\end{array}$ & $\begin{array}{c}\mathbf{P b} \\
(\mathbf{m g} / \mathbf{l})\end{array}$ & $\begin{array}{c}\mathbf{C d} \\
(\mathbf{m g} / \mathbf{l})\end{array}$ & $\begin{array}{c}\mathbf{C r} \\
(\mathbf{m g} / \mathbf{l})\end{array}$ & $\begin{array}{c}\mathbf{C u} \\
(\mathbf{m g} / \mathbf{l})\end{array}$ & $\begin{array}{c}\mathbf{N i} \\
(\mathbf{m g} / \mathbf{l})\end{array}$ & $\begin{array}{c}\mathbf{Z n} \\
(\mathbf{m g} / \mathbf{l})\end{array}$ & $\begin{array}{c}\mathbf{C o} \\
(\mathbf{m g} / \mathbf{l})\end{array}$ & $\begin{array}{c}\mathbf{M n} \\
(\mathbf{m g} / \mathbf{l})\end{array}$ \\
\hline Seyitömer & 0,51 & 0,09 & 3,06 & 0,05 & 1,38 & 0,11 & 0,59 & 0,16 \\
\hline Tunçbilek & 0,17 & 0,06 & 3,51 & 0,05 & 1,01 & 0,05 & 0,42 & 0,16 \\
\hline Yatağan & 2,01 & 0,31 & 3,05 & 0,33 & 3,01 & 0,23 & 1,84 & 0,41 \\
\hline Soma & 3,17 & 0,33 & 6,16 & 0,36 & 4,48 & 0,23 & 2,25 & 0,51 \\
\hline
\end{tabular}

Çizelge 9. Uçucu kül örneklerinden suya ağır metal liç verimi (\%)

\begin{tabular}{|c|c|c|c|c|c|c|c|c|}
\hline $\begin{array}{c}\text { Termik } \\
\text { Santral }\end{array}$ & $\begin{array}{c}\mathbf{P b} \\
(\boldsymbol{\%})\end{array}$ & $\begin{array}{c}\mathbf{C d} \\
(\boldsymbol{\%})\end{array}$ & $\begin{array}{c}\mathbf{C r} \\
(\boldsymbol{\%})\end{array}$ & $\begin{array}{c}\mathbf{C u} \\
(\boldsymbol{\%})\end{array}$ & $\begin{array}{c}\mathbf{N i} \\
(\boldsymbol{\%})\end{array}$ & $\begin{array}{c}\mathbf{Z n} \\
(\boldsymbol{\%})\end{array}$ & $\begin{array}{c}\mathbf{C o} \\
(\boldsymbol{\%})\end{array}$ & $\begin{array}{c}\mathbf{M n} \\
(\boldsymbol{\%})\end{array}$ \\
\hline Seyitömer & 1,02 & 4,48 & 0,73 & 0,05 & 0,11 & 0,02 & 0,66 & 0,03 \\
\hline Tunçbilek & 1,04 & 3,08 & 1,18 & 0,14 & 0,20 & 0,02 & 0,90 & 0,02 \\
\hline Yatağan & 4,17 & 8,03 & 3,72 & 0,51 & 3,05 & 0,05 & 3,73 & 0,13 \\
\hline Soma & 6,35 & 16,50 & 9,49 & 0,79 & 6,45 & 0,06 & 5,67 & 0,27 \\
\hline
\end{tabular}

* Uçucu küllerde bulunan ağır metal miktarları ve suya geçiş oranları birlikte değerlendirilirse; En yüksek oranda nikel, krom ve bakır içeren Seyitömer Termik Santrali külünden bu metallerin suya geçişleri diğer uçucu küllerden düşük olmuştur. Soma termik santrali külü, Seyitömer ve Tunçbilek Termik Santrali ile yakın oranlarda kadmiyum içermesine rağmen, en yüksek kadmiyum liçi Soma termik santrali uçucu külünde olmuştur. Yine en az miktarda kobalt içeren Soma termik santrali uçucu külünden en yüksek yüzdede $(\% 5,67)$ kobalt liçi olmuştur. Bu sonuçlar, uçucu küllerin ağır metal içerikleri ile liç karakteristiklerinin birbirinden farklı olduğunu göstermiştir.

* Uçucu küllerden suya liç işlemlerinin beşinci günün sonunda tamamlanması ve gözlenen geçişin en yüksek \% 16,50 (Soma-Cd) olmas1, kötü yönden doğada da ağır metal liçinin çok hızlı gerçekleşeceğini, iyi yönden uçucu küllerin bünyelerindeki ağır metallerin, küllerin içerisindeki diğer minerallerce bağlanmış olduğunu göstermektedir. $\mathrm{Bu}$ ağır metallerin tutulması kirliliğin artmasını önlemekle birlikte, daha düşük pH'larda ağır metal liçinin artma eğiliminde olduğu bilinmektedir.

* XRD analizleri ile belirlenen minerallerin ve SEM görüntüleri ile belirlenen fiziksel özelliklerin, uçucu küllerin bünyesinde bulunan ağır metalleri nasıl tuttukları, tutunmanın fiziksel adsorpsiyon mu yoksa kimyasal adsorpsiyon mu olduğu henüz bilimsel çalışmalarla belirlenmemiştir. Bu konuda daha detaylı çalışmalar yapılabilir.

\section{TEŞEKKÜR}

$\mathrm{Bu}$ çalışma, MMF2006D4 nolu proje olarak, Çukurova Üniversitesi Araştırma Projeleri Birimi 
tarafından desteklenmiş olup, Doktora tezinden alınmıştır.

\section{KAYNAKLAR}

1. TTK (Türkiye Taşkömürü Kurumu), 2014. Taşkömürü Sektör Raporu 2013. Mayıs 2014.

2. TKİ (Türkiye Kömür İşletmeleri), 2014. Kömür Sektör Raporu (Linyit) 2013. Haziran 2014.

3. Öteyaka, B., Uçar, A., Şahbaz, O., Demir, U., Yamık, A., 2006. Seyitömer Linyit Yatağı B1+B2 Damarlar1 Kömürlerinin Yıanabilirliğinin Araştırılması. Türkiye 15. Kömür Kongresi Bildiriler Kitab1, 07-09 Haziran, s 371-383, Zonguldak.

4. Watson, J.S., 1985. Potentional Resources from Coal Fly Ash. Mat. Res. Soc. Symp. Proc., 43: 151-161.

5. Fischer, G.L., Natusch, D.F.S., 1978. Size Dependence of the Physical and Chemical Properties of Coal Fly Ash. Anal. Mtd. Coal Prod., 3: 489- 541.

6. Burnet. G., 1986. Never Technologies for Resource Recovery from Coal Combustion Solid Wastes, Energy Vol. 11, No 11/12 pp. 1363-1375.

7. Baykan, A.R., 2004. Türkiye Çevre Atlası. T.C. Çevre ve Orman Bakanlığı ÇED ve Planlama Genel Müdürlüğü Çevre Envanteri Dairesi Bşk., Ankara.

8.TS 12088 Ekim 1996. Katı Atıklar-Ağır Metal Tayini-Atomik Absorbsiyon Spektrofotometrik metot.

9. TS EN 12457-3 Ocak 2004. Atıkların Nitelendirilmesi-Katıdan Özütleme AnaliziGranül Katı Atıkların ve Çamurların Katı Özütlemesi Deneyi: Bölüm 3.

10. TS EN ISO 15586 Ocak 2004. Su kalitesiGrafit Firınlı Atomik Absorbsiyon Spektrometresi (AAS) Kullanılarak Eser Elementlerin Tayini.

11. Ramesh, A., Kozinski, J.A., 2001. Investigations of Ash Topography/ Morphology and Their Relationship with Heavy Metals Leachability. Environmental Pollution 11:255-262.

12. Li, M., Xiang, J., Hu, S., Sun, L.S., Su, S., Li, P.S., Sun, X.X., 2004. Characterisation of Solid
Residues from Municipal Solid Waste Incinerator. Fuel 83:1397-1405.

13. Liu, G., Zhang, H., Gao, L., Zheng, L., Peng, Z., 2004. Petrological and Mineralogical Characterisations and Chemical Composition of Coal Ashes From Power Plants in Yanzhou Mining District, China. Fuel Process Technol 85:1635-1646.

14. Seredin, V., Finkelman, R., 2008. Metalliferous coals: A Review of the Main Genetic and Geochemical Types. International Journal of Coal Geology, 76, 253-289.

15. Clarke, L.B., Sloss, L.L., 1992. Trace Elements-Emissions from Coal Combustion and Gasification. London, IEA Coal Research, 111.

16. Ünalan, G., 2010. Kömür Jeolojisi, Maden Tetkik ve Arama Genel Müdürlüğü Eğitim Serisi-41, Ankara.

17. Fotopoulou, M., Siavalas, G., İnaner, H., Katsanou, K., Lambrakis, N., Christanis, K., 2010. Combustion and Leaching Behavior of Trace Elements in Lignite and Combustion byProducts from the Muğla Basin, SW Turkey. Bulletin of the Geological Society of Greece, Proceedings of the $12^{\text {th }}$ International Congress, Patras.

18. Wang, Y., Ren, D., Zhao, F., 1999. Comparative Leaching for Trace Elements in Raw Coal, Laboratory Ash, Fly Ash and Bottom Ash. International Journal of Coal Geology, 40, 103-108. 